\title{
Metafore iz grško-rimskega sveta v delih slovenskega pisatelja Alojza Rebule
}

\author{
JADRANKA CERGOL \\ Univerza na Primorskem, Znanstveno-raziskovalno središče; \\ Univerza na Primorskem, Fakulteta za humanistične študije, Titov trg 5, \\ SI-6000 Koper, jadranka.cergol@zrs.upr.si
}

\begin{abstract}
Članek se osredotoča na analizo nekaterih primer in metafor v delih slovenskega pisatelja Alojza Rebule, in sicer upošteva samo tiste, ki imajo kot predmet metafore prispodobe iz klasičnega grško-rimskega sveta. Na podlagi interacijske teorije metafore avtorica predstavi antiko najprej kot glavni predmet, nato kot stranski predmet, v zaključnem delu pa odkriva, kaj pomeni za pisatelja Alojza Rebulo interakcija.
\end{abstract}

The paper presents a detailed analysis of certain similes and metaphors in the works of the Slovene writer Alojz Rebula, focusing mainly on the metaphors that have Graeco-Roman similes as their subject. Based on the interaction theory of metaphor the author first presents classical antiquity as the primary subject, and later on as the secondary subject. The last part of the paper focuses entirely on the meaning of interaction in the literary works of Alojz Rebula.

Ključne besede: Alojz Rebula, antika, interacijska teorija metafore, humanitas

Key words: Alojz Rebula, classical antiquity, interaction theory of metaphor, humanitas

\section{Znanstvena izhodišča}

Evropa mi ni nič več kot metafora.

Zamenljiva $z$ abstraktno humanitas ali anthropejo. (Alojz Rebula)

Rebulov opus je nedvomno pretkan z bogato metaforiko, ki delno izvira iz poznavanja grško-rimskega sveta. Cilj pričujočega prispevka je analizirati nekatere od teh metafor $\mathrm{z}$ uporabo interacijske teorije metafore in razumeti, katere so tiste interakcije, ki po mnenju slovenskega pisatelja povezujejo antični in sodobni svet. 
Termin metafora izvira iz starogrških besed meta (preko, čez) in fero (nosim), njen osnovni pomen je torej prenos. Prvo razlago o metafori srečamo v Aristotelovi Poetiki, kjer beremo, da je metafora »prenos pomena na neko drugo besedo, in sicer ali od splošnega na neko vrsto ali od neke vrste na splošno ali od ene vrste na drugo vrsto ali po analogiji« (Aristotel 1982: 96).

Po mnenju grškega filozofa je torej poglavitna funkcija metafore tvorjenje novih poimenovanj ter da je med različnimi »nenavadnimi izrazi« metafora tista, katere se ne da priučiti, sposobnost ustvariti metaforo pa je sposobnost odkriti podobnosti med stvarmi (Aristotel 1982: 101).

Med klasične teorije metafore spada tudi primerjalna teorija, ki prav tako izvira iz antičnih, tokrat rimskih, retorikov Cicerona in Kvintlijana. Tudi onadva sta menila, da je metafora posebnost govora, predvsem pa da gre za primerjanje dveh pojmov in iskanje stičnih točk med le-temi. Iz Aristotelovega pojmovanja metafore se je v 20. stoletju razvila substitucijska teorija metafore, ki pojmuje metaforo kot nek odklon oziroma jezikovno posebnost in jo je mogoče ustrezno zamenjati z dobesednim izrazom (Čeh Steger 2005: 76), ob njej pa je nastala še interakcijska teorija metafore, ${ }^{1}$ predvsem kot kritika primerjalni teoriji, saj trdi, da metafora ne nastane iz primerjanja in da je ni mogoče nadomestiti $\mathrm{Z}$ dobesednim izrazom (Kurz 1988: 8). Bistvo interakcijske teorije je v procesu, ki se odvija v metafori, torej $\mathrm{v}$ ubeseditvi dveh idej, ki delujeta istočasno; teorija besedo obravnava kot:

/.../ del živega diskurza, ki se lahko nanaša le na okoliščine in ni generičen, temveč uveljavljen le v vsakodnevni realizaciji. Kontekst torej izbira variante ustreznega pomena besede, katere celotni pomen je sestavljen iz središčnih in perifernih pomenov (Matajc 1996: 75).

Po mnenju začetnika interacijske teorije metafore Ivorja A. Richardsa nastane metafora takrat, ko imamo »dve misli o dveh različnih stvareh, ki delujeta skupaj, a se naslanjata na eno besedo, katere pomen je rezultanta njune interakcije« (Richards 1998: 45). Richards je za dvočlensko razdelitev metafore uporabil termina tenor in vehicle. V slovenski terminologiji sta se uveljavila prevoda vsebina in prenosnik: vsebina je to, kar želi avtor z metaforo izraziti, prenosnik pa je oblika, v kateri izrazimo vsebino. To, kar združuje oba člena oz. njuna interakcija, Richards imenuje tenzija, ki je »rezultanta (novega) pomena in je drugačna od pomena izoliranega tenorja ali izoliranega vehikla« (Matajc 1996: 78). Po Richardsu vsebuje metafora tudi primerjavo dveh elementov, včasih je to zgolj vzporejanje dveh stvari, da bi delovali skupaj, včasih pa je proučevanje obeh, da bi videli, $v$ čem sta si podobni in v čem se razlikujeta (Richards 1998: 60-64).

Glavni utemeljitelj interakcijske teorije metafore je bil Max Black, ki je »metaforo pojmoval kot besedno ali stavčno zvezo, v kateri mora biti vsaj ena beseda uporabljena metaforično (žariščée), hkrati pa vsaj ena dobesedno (okvir).

${ }^{1}$ Termina substitucijska teorija metafore in interakcijska teorija metafore izvirata iz utemeljitelja slednje Maxa Blacka (Black 1998). 
Metafora je sestavljena iz žarišča in okvira ter zahteva bralčevo aktivnost, saj je razumljena kot odnos, v katerem stopa žarišče v okvir metaforične izjave« (Čeh Steger 2005: 77). Kasneje je Black uvedel dva nova pojma, in sicer glavni in stranski predmet, pri čemer pa je dodal, da ju je treba vedno jemati kot sistem, ki deluje $\mathrm{v}$ interakciji. Interakcijo med glavnim in stranskim predmetom Black pojmuje kot proces,

/.../ v katerem sistem asociiranih občih mest, pozneje imenovan sistem implikacij, recipienta navede $\mathrm{k}$ izgradnji ustreznega sistema implikacij glavnega predmeta. /.../ Nove implikacije glavnega predmeta določa skupek implikacij, asociiranih z dobesedno rabo besede, ki označuje stranski predmet, tako da se neke implikacije oziroma lastnosti glavnega predmeta izpostavijo, druge, $\mathrm{v}$ tem primeru neustrezne, pa potisnejo v ozadje. $\mathrm{S}$ tem celotna metafora (na novo) organizira recipientovo razumevanje glavnega predmeta oziroma stranski predmet filtrira vse aspekte in transformira vse ustrezne aspekte glavnega predmeta. Glavni predmet s pomočjo metafore tako začne implicirati lastnosti ali aspekte, ki jih normalno pripisujemo stranskemu predmetu (Matajc 1996: 79-80).

Iz navedenega sledi, da gre pri uporabi metafore za dva pojma (tenor in vehicle / glavni in stranski predmet), ki se med sabo prepletata in ustvarjata interakcijo, ki vsebuje značilnosti obeh pojmov, ima pa izredno subjektivni značaj. Če to razmišljanje uporabimo za prikaz bogate Rebulove metaforike, ki je povezana $\mathrm{z}$ antiko, jo lahko razčlenimo na tri različne nivoje: $\mathrm{v}$ nekaterih primerih je antika uporabljena $\mathrm{v}$ interakcijskem smislu glavnega predmeta, $\mathrm{v}$ drugih stranskega; interakcija med tema dvema pa so tiste univerzalne silnice, ki združujejo tako antični kot sodobni svet.

\section{Antika kot glavni predmet}

Literarna veda je že dokazala, da antika bistveno pogojuje miselni svet slovenskega pisatelja Alojza Rebulo (Gantar 2005; Cergol 2006, 2011; Rebula 2011). Veliko se o njej pogovarjajo Enej Silvij Piccolomini in Tilen s Kontovela, Amos Borsi in Stanko Križnik, ne nazadnje se pisatelj sam večkrat prepusti domišljiji ter z mislijo poleti na grška ali rimska tla. V analitičnem delu članka bodo predstavljeni nekateri citati, $\mathrm{v}$ katerih bodo metafore podčrtne: $\mathrm{v}$ tem razdelku bodo izpostavljene tiste metafore, ki imajo antiko kot glavni predmet, $\mathrm{v}$ naslednjem pa kot stranski predmet. Največ metafor $\mathrm{z}$ antično vsebino nedvomno zasledimo v romanu $V$ Sibilinem vetru. V mitu o Kleobisu in Bitonu, ki ga mladi Nemezian napiše za Laterana, gre za zgodbo dveh bratov, ki vestno pomagata očetu pri delu na polju. Njuna mati je svečenica Herinega templja v Argosu, a v starejših letih si zaradi telesne šibkosti ne upa več sama peš do templja, tako da jo na vozu, ki ga vlečeta dva bika, pelje mož. Nekega dne mož zakasni, mati pa mora zaradi obreda čim prej v tempelj. Ker očeta in bikov ni na spregled, se brata odločita, da bosta kar sama vlekla voz do svetišča po zelo naporni poti. Obiskovalci templja se marljivima fantoma čudijo, a njuna mati je zelo ponosna, tako da za njiju izprosi pri boginji to, kar je za človeka najboljše. Brata se medtem uležeta $v$ travo, da bi se odpočila, tam tudi zaspita 
»kai ouk anestesan « in se nikoli več ne prebudita. Celotna zgodba o Kleobisu in Bitonu je seveda metafora za neizmerno ljubezen sinov do matere: taka vsaj je bila najobičajnejša interpretacija te zgodbe, na katero sam Rebula namiguje v romanu, ko se sprašuje:

Katera je bila tista mati, ki sva jo, nova Kleobis in Biton, vozila proti prividnemu svetišču, ki se je imelo zdaj zdaj prikazati tam na gori iz rumenih vrtincev? (Rebula 1968: 489)

Nova Kleobis in Biton sta medbesedilna metafora za sinovo ljubezen do matere, $\mathrm{v}$ tem primeru pa je tista mati metafora za Marijo, Jezusovo mati, ki jo Rebula spretno in pesniško postavi $\mathrm{v}$ interakcijo $\mathrm{z}$ grškim mitom in tako poveže antično ter krščansko miselnost $\mathrm{v}$ skupno interkacijo, ki $\mathrm{v}$ tem primeru predstavlja metaforo za sinovo ljubezen do matere, ki je prisotna tako v enem kot drugem izročilu.

Po Herodotovi pripovedi pa je možna tudi druga interpretacija mita: brata Kleobis in Biton sta od boginje dobila v dar to, kar je za človeka najboljše nebolečo smrt, ki jo Rebula pesniško ponazori z metaforo kai ouk anestezan - in se nista več prebudila. In dejansko predstavlja mit tisto plat grške duše, ki je po Sofokleju iz svoje globočine zakričala: »Ne roditi se: to je beseda vseh besed!«. Grški filozof je spoznal tudi najbolj kruto in najbolj tragično plat človekove eksistence in si je zato na skrito zaželel le smrti. Tragičnost življenja je od njega prevzel tudi Rebula in jo učinkovito ponazoril z mitom o Kleobisu in Bitonu, $\mathrm{k}$ temu pa dodal še neštetokrat ponovljene Sofoklejeve besede.

Ob smrti veličastno kraljuje človekovemu življenju tudi Hronos, bog bežečega časa:

a tudi Lotosova poljana ni bila večnost, bila je čas, čeprav preklet. Vse je bilo samo čas, Hronos, ki je požiral. In nekega dne je prišla do nas vest, da so njegove čeljusti hlastile po vrhu-Lucija Vera ni bilo več. (Rebula 1968: 433)

Rebula je v tem odlomku izrazil svojo misel, kako neizprosno bežeči čas privede človeka do smrti, in se ob tem spraševal, kakšen smisel ima torej sploh življenje, če se bo vse, kar delamo, vse, kar doživljamo, nekega dne spremenilo v prah, prešlo $\mathrm{v}$ temine sveta in $\mathrm{v}$ nič. Pisatelj se zaveda, da se je svojega izginotja tudi antični človek neizmerno bal in zaradi grozečega niča se mu je zdela tudi človekova usoda absurdna. V svoji brezupni tragiki pa si je skušal osmisliti življenje: izrisal si je svojo podobo posmrtnega življenja. Del te predstave so npr. Elizejske poljane, kjer po smrti nadaljujejo svoje življenje dobri ljudje, del iste podobe je tudi reka Aheront s svojim pritokom Kokito, čez katero so bile duše umrlih pripeljane na drugi breg. Ta motivika zelo jasno izstopa npr. v Božanski komediji, v kateri Dante preoblikuje navedeni prikaz z mnogimi drugimi elementi in skuša tako združiti antično predstavo sveta s krščansko. To je tudi v samem Rebuli vzbudilo takšno pozornost, da se je pri izbiri svoje doktorske disertacije odločil za Danteja. Ob Aherontu navaja Rebula še dve pomembni reki: Lete in Evnoe, ki sta $\mathrm{v}$ tem primeru metafori za pozabo in prerojenje. 
Mozaik ves svetal, ko da bi bil pravkar sestavljen in umit. Na njem zavoja dveh rek, Lete in Evnoe. In med reko pozabe in med reko prerojenja gozd s sadeži, koničastimi in redkimi kakor šipek. (Rebula 1968: 194)

Nekatere duše umrlih so se namreč po antični mitologiji očistile v reki Lete, kjer so popolnoma pozabile na prejšnje življenje, in nato po prestopu v drugo telo zaživele novo življenje. Reko Evnoe poznamo tudi iz Dantejevih Vic: duše umrlih so se po Danteju najprej okopale v Leti in tam pozabile na svoje življenje, nato pa še v Evnoji, reki prerojenja, ki je vrnila spomin na dobra dela in očistila dušo slabih dejanj ter jo pripravila za vstop v Eden. Tako se grško-rimska mitologija pri Rebuli večkrat prepleta z drugimi evropskimi kulturnimi izročili, ostaja pa vendarle vedno v ospredju.

$\mathrm{V}$ ostalih Rebulovih delih naletimo še na druge metafore, ki izpričujejo, kako je antični svet iskal možni izhod iz tragičnosti življenja. Stari Grk si je skušal osmisliti bivanje na zemlji na najrazličnejše načine, kot npr. z Afrodito, boginjo ljubezni:

Ti si me popeljala $v$ hlev, jaz te popeljem v globino morja. Zelene votline, odbleski počivajočih rib, tihi nihljaji svetlega lasastega rastlinja. Tam se utrne mehurček. Počasi ga začne nesti navzgor, zeleni prepadi postajajo čedalje bolj prosojni, dokler ne splava na površje. Tam se razdihne v belkasto peno in iz pene se izvije v mokre deviške boke Afrodita, boginja ljubezni. (Rebula 1968: 40)

Afroditi je v grški literaturi posvečenih veliko verzov, bogatih metafor in poetičnih stavkov, to pa verjetno tudi zato, ker je boginja personifikacija silne energije, to je energije ljubezni. Sam Platon jo je v svojem Simpoziju opisal z nekaterimi izbranimi prispodobami. Vse to nam dokazuje, da je ta tako imenovani »peti element« predstavljal tudi za Grka neusahljivi vir sveže in močne življenjske sile. Rebula uporablja za Afrodinitino rojstvo metaforo mehurčka, torej nekaj nežnega, čistega, ki se nato spremeni v belkasto peno in iz pene se rodi sama ljubezen: $\mathrm{v}$ tem primeru gre za prepričljivo metaforo o rojstvu ljubezni, ki se lahko rodi iz čistega in nežnega trenutka in se nato razbohoti v mogočno silo. Mogoče je najbolj doživete verze posvetila boginji Afroditi pesnica Sapfo, tako kot trdi Rebula:

Vrabčki, Afroditini ptički, se bodo vpregli v zlati voz, da nama pripeljejo tisto uro, "gosto trepetajočo s perutmi skozi sinjino,« kakor v Sapfini pesmi. (Rebula 1968: 458)

$\mathrm{Ob}$ navedenih metaforah stopa $\mathrm{v}$ ospredje antika kot glavni predmet, torej $\mathrm{v}$ smislu tistega filozofskega pojmovanja življenja in smrti, ki izhaja iz besedil antičnih piscev. Iz teh lahko zasledimo Rebulovo pojmovanje antike v tragični luči doživljanja absurdnosti sveta in življenja nasploh. Kopica njegovih primerov jasno nakazuje, kako si je skušal stari Grk osmisliti tragičnost bivanja, najpogosteje $\mathrm{z}$ ljubeznijo. Značilne pa so tudi Rebulove metafore, usmerjene v lastno literarno ustvarjanje, ki je upodobljeno z Muzami, deveterimi mitološkimi bitji, ki že tisočletja navdihujejo umetnike. Muze so v tem primeru metafora za literarno ustvarjanje, ki Rebuli pomeni uteho. 
Le da ni pozabilo nanj neko drugo carstvo - le da niso pozabile nanj Muze. Res, to ni bila več nekdanja brezmejna mladostna ljubezen, a vendar - tudi v to leščevje, $v$ to šipkovje in brinje so mu morale slediti božanske hčerke kršnega Helikona. /... Samo nje, tolažbe polne, nenevarne, nepolitične, nediplomatske, si je želel v ta kot patriarhije in cesarstva. (Rebula 1968: 24)

Ob tragičnosti človekovega bivanja, ob mitološki predstavi posmrtnega življenja, ob ljubezni in pesniškem navdihu, ki jih je Rebula odkril v grško-rimskem pojmovanju sveta in iz njega zajemal metafore za to, v kar je pravzaprav tudi sam verjel, se lahko vprašamo, kaj pomeni tržaškemu avtorju antika sama na sebi. Pisatelj jo v Zelenem izgnanstvu upodablja kot »sanjo, ki je ne bo nikoli izsanjal « (Rebula 1981: 244). Antika je torej zanj le metafora za sanje, v katero se zelo rad zateka, kar nam pričajo številni lirični opisi veličastne grške umetnosti. To je tista antika, ki se Rebuli razkriva pod tančico sanj, to je čas, ki ga Rebula neprestano živi in ga ne bo nikoli nehal sanjati, tako da se bo lahko še dalje »okopal v svoji klasiki« (Rebula 2000: 133). Zatopljenost v branje antičnih avtorjev, poglabljanje v njihov svet poteši Rebuli »potrebo po pozabi, po preteklosti« (Rebula 2000: 164), saj se tako lahko nahrani »z Avguštinovim srčno-miselnim mozgom, se potolaži s sinjino in zlatom Homerjevega heksametra« (Rebula 2000: 220).

Sodeč po navedenih metaforah, lahko sklepamo, da je avtor popolnoma vživet v antiko, da se oplaja bodisi ob njenem spoznanju tragičnosti človekovega bivanja kot ob njeni veličini pri premagovanju te tragičnosti. Grštvo je za Rebulo tako kot »iz suhega zlata uliti krater, ki naj zajame vino z Jessove sadike« (Rebula 1971: 97).

Ko pa se pobliže seznanimo še z drugo vrsto metafor, v katerih igra antika vlogo stranskega predmeta in v katerih je v ospredju sodobni človek, ki se ozira nazaj, da bi iz antike črpal nauke za boljše prenašanje svojega tragičnega bivanja na tem svetu, opazimo, da Rebula ne živi zgolj v antiki, ampak se nanjo ozira tudi s pogledom sodobnega človeka.

\section{Antika kot stranski predmet}

V Rebulovih delih so tovrstne metafore, ki imajo antiko kot stranski predmet, številčno veliko bolj pogoste. Njihovo težišče je sedanji svet, ki ga pisatelj primerja $\mathrm{z}$ antičnim in bogati z nekaterimi iz njega izhajajočimi prispodobami ter tako poudarja, da je človekova eksistenca pravzaprav vedno ista, da so že stari Grki in Rimljani odkrili skoraj vse možne razsežnosti človekovega zemeljskega bivanja. Metafore so lahko v tem primeru enostavne ali pa daljše, bolj kompleksne in globlje besedne zveze. Ob poglabljanju v metafore opazimo, da le-teh ni malo. Najprej se nam pred očmi pojavi naslov prve zbirke novel Vinograd rimske cesarice, ki ne ponazarja dejansko vinograda rimske cesarice, temveč je le metafora, ki jo italijanski nacionalisti uporabljajo proti postavitvi dvojezičnih tabel na kraški planoti, češ da ne morejo na tem kraju, 
kjer je pred dva tisoč leti stal vinograd, ki ga je vzljubila sama rimska cesarica, živeti Slovenci. Podobna metafora se kasneje pojavi še v drugih delih, npr. v romanu Maranathà, ko duhovnik v samostanu ponuja junaku »vino, ki je šlo v slast Liviji, cesarici« (Rebula 1996: 58).

$\mathrm{Na}$ ravni metafor vzbujajo pozornost tudi številna imena grških mest, tako npr. Gorica živi v Rebulovem spominu kot »Primorske Atene» (Rebula 1990: 15), ker pojmuje mesto kot središče kuturnega dogajanja na Primorskem (tako kot so bile Atene v stari Grčiji), Loka pri Zidanem mostu, kamor se pisatelj večkrat zateka in v zadnjih letih preživlja večji del svojih dni, je zanj »obsavski Tuskulum « (Rebula 1993: 28), gre torej za metaforo tistega mesta, v katerem je Ciceron zelo rad preživljal svoj prosti čas in se posvečal pisateljevanju in razmišljanju, celotna Štajerska pa ga navdaja z občutkom, da se nahaja v samem srcu slovenske Atike (Rebula 1995: 34).

Podobni občutki zajamejo Rebulo ob ogledu najrazličnejših kulturnih biserov po svetu, predvsem v Ameriki, tako npr. na sprehodu po torontski univerzi pravi, da "gre v živahnem pomenku skozi to Aleksandrijo, če že ne Atene tukajšnjega protestantizma « (Rebula 1986: 182).

Zelo priljubljena prispodoba za številna slovenska mesta (med temi izstopa predvsem Trst) so Tebe. Po grški mitologiji so Tebe simbol bratomorne vojne med Eteoklom in Polinejkom, v kateri se oba brata med spopadom znajdeta drug proti drugemu in se $\mathrm{v}$ krvoločnem boju pobijeta. Mit se nadaljuje $\mathrm{z}$ veličastno osebnostjo njune sestre Antigone, ki sledi le glasu svoje vesti in proti državniški volji pokoplje brata - za državo izdajalca. Tebanska vojna je posebno izstopajoča in jasna prispodoba za bratomorno vojno med Slovenci, ki večkrat zaposluje Rebulovo razmišljanje o usodi slovenskega naroda. Zato si avtor zaželi prihoda slovenske Antigone, ki bi poravnala dolg in potresla pepel na vse vojne žrtve. Trst in z njim celotno slovensko ozemlje postanejo tako Slovenske Tebe:

Slovenske Tebe, s slovenskim Eteoklom in slovenskim Polinejkom. In glas iz kripte se dobesedno spominja besed, ki sta si jih zavpila, leže na trebuhu vsak za svojim orožjem. Partizan: »Pridi k nam, ker si na napačni potil« Legionar: »Povej: kam si dal rožni venec, ki ti ga je mati dala? « Slovenska Antigona, potresi prst nad mrtvimi slovenskimi brati! (Rebula 1985: 86)

Prav tako so tudi osebe, ki jih Rebula srečuje na svoji življenjski poti, ogrnjene v bogato metaforiko. Svojega prijatelja Edvarda Kocbeka npr. imenuje "slovenski Tukidid in slovenski Ksenofont v eni osebi« (Rebula 1991: 136), nanašajoč se pri tem na njegove dnevniške zapise, ki hranijo v sebi neizmeren zaklad zgodovinskih podatkov, prav tako kot sta Tukidid in Ksenofont glavni vir informacij za poznavanje grške zgodovine: oba sta v evropski literaturi položila trdne temelje zgodovini, čeprav gre za stilno različna pisca. Kocbek je združil pragmatično in razumsko Tukididovo opisovanje dogodkov z bolj sproščenim in anekdotičnim Ksenofontovim pripovedovanjem, vsaj tako meni Rebula.

Samega sebe pa tržaški pisatelj označuje za »krotkega slovenskega Dioniza« (Rebula 1994a: 31), pri čemer želi podčrtati svojo značajsko odprtost in nagnjenost $\mathrm{k}$ sproščenosti: 
Vse do zdaj sem mislil, da le vem, kaj je smeh, čeprav nisem rojen pod znamenjem Apolona, ampak Dioniza. (Rebula 1986: 280)

Dionizu, bogu vina, rodovitnosti pa tudi veselega in brezskrbnega razpoloženja, simbolu tiste človekove plati, ki je nagnjena $\mathrm{k}$ iracionalnosti, postavi Rebula nasproti Apolona, boga glasbe, sonca in racionalnosti, tako da si včasih »zaželi apoliničen večer« (Rebula 2001: 23). Podobnih metafor je kar precej. Tako je npr. maj v letu 1945 poimenovan kot »Ajshilov maj '45 « (Rebula 1986: 179), saj je bil dejansko eden najbolj krvoločnih in grozovitih majev v zgodovini slovenskega naroda, prav tako kot so grozovite in krvoločne Ajshilove tragedije. Prispodobo iz Homerjeve Odiseje pa uporabi Rebula v Sibilinem vetru, kadar junak romana pristane na grški obali in misli, da je bilo prav »homersko, ko je ladja pristala $k$ obali iz rdečkaste zemlje in se je nanjo vsul vrišč skržatov $s$ črnik« (Rebula 1968: 463). Odisej je tu izraz za tisto notranjo strast, ki drži človeka priklenjenega na svojo zemljo in ga veže, da bi na njej tudi ostal. Rebula imenuje takšno občutje »odisejevska strast « (Rebula 2000a: 12).

Spet drugje pooseblja besedni namig na antiko rdeča barva zemlje, ki vliva »pompejansko« razpoloženje, »v tisti melanholični antični rdečini, ki spominja na mešanico krvi in opeke (Rebula 1986: 48). Mesto Pompeji v bližini Neaplja je danes znano arheološko najdišče, čeprav ga je v antiki zalila lava, ki je bruhala iz Vezuva. Še vedno pa ohranja podobo antičnega mesta, ki spominja na mešanico krvi in opeke prav zato, ker so opeke dejansko rdeče barve, ob njih pa zaživi še spomin na množico žrtev, ki jih je terjal izbruh vulkana.

Potovanje po Grčiji je v Rebuli vzbudilo vse mogoče občutke in reminiscence iz grške literature, tako da je bilo »jonsko-homersko, egejsko-sanjsko ob 8.25 odpeljati se po Ahilovi« (Rebula 2001: 12). Večkrat se avtor tako vživi v Homerjeve epe, da "sliši peket konja na cesti: in je kakor glas iz Iliade" (Rebula 1986a: 64).

Dalje naletimo še na metafore, ki predstavljajo interakcijo za nekatere pojme: tako se npr. oče glavnega junaka v romanu Cesta s cipreso in zvezdo pogovarja s sinom o tem, da je pred časom zavrgel slovensko služkinjo, ker bi ta »skalila ozračje v družini in naredila iz vas kalne dvojezičneže, hermafrodite, razklance, značaje brez prozornosti« (Rebula 1998: 53). Hermafrodit je bil sin Hermesa in Afrodite in se je - po grški mitologiji - zaljubil v nimfo Salmako. Prosil je bogove, da bi bil lahko za vedno združen z njo. Ti so njegovo prošnjo uslišali in tako iz dveh naredili eno samo telo; gre torej za metaforo hkratne dvospolnosti.

Spet $\mathrm{v}$ drugih metaforah Rebula razmišlja o sodobnem človeku, ki jih utrjuje s primerami iz antičnega sveta in s tem dokazuje, da so silnice, ki vladajo življenju, vedno iste. Metaforo te vrste srečamo v romanu Kačja roža, v katerem se med junakom Amosom Borsijem in Stankom Križnikom, slovenskim študentom klasične filologije, stke globoka prijateljska vez. Njun odnos se je rodil iz Amosove želje po spoznavanju slovenskega jezika: med pogovori in učnimi urami se je med njima ustvarila taka vez, da je spominjala na 
tisto mitično prijateljsko dvojico - mar nisva tudi midva bila svojevrstna Pilad in Orest in nisva hodila tudi midva po svojevrstnem Hersonezu, v pogrebnem brinjevem vonju? (Rebula 1994: 76)

$\mathrm{V}$ interpretaciji antičnega mita veljata namreč Pilad in Orest za nerazdružljiva prijatelja, ki si v težavah pomagata.

Zgodba o Orestu, ki ubije svojo mater, da bi se maščeval nad umorom očeta, je ostala zapisana v svetovni literaturi kot ena najbolj tragičnih in nam je znana predvsem po Ajshilovi trilogiji Oresteja, ki na zelo krut način postavi na oder Orestovo usodo. Potem ko njegova mati Klitemnestra ubije očeta, se Orest namreč zateče $\mathrm{k}$ stricu in tam preživi veliko let, obenem pa goji globoko prijateljstvo s Piladom, ki ga nato pospremi nazaj v Mikene. Tam se Orest maščuje nad materjo in jo ubije. A to dejanje je zanj usodno: začnejo ga mučiti in preganjati grozovite Erinije, katerih se ne more rešiti. Odpluje čez morje, na Hersonez, v Artemidin tempelj, da bi tam našel mir, a vse zaman. Pri tem ga neprestano spremlja in mu stoji ob strani prijatelj Pilad.

Ko sem se naslednji dan Stanku oglasil s kartico iz Benetk, sem jo naslovil Piladu Križniku, samega sebe pa podpisal Orest. I...I In s kakšno pretresenostjo sem potem od Stanka zvedel, da je Prě̌eren napisal verz zame: "Erinije vse so se ga polastile..." (Rebula 1994: 76)

Ne gre torej le za opis prijateljske navezanosti, ampak tudi za podoživljanje mitoloških bitij, Erinij, ki so Oresta neprestano preganjale in obsedale. Podobno se dogaja tudi Amosu: sam se ima za Oresta, ki blodi po Hersonezu, potem ko so se ga polastile Erinije. V težki dobi fašizma, ko ga mučijo in plašijo antisemitske Erinije, ga spremlja prijatelj Stanko - Pilad. Prijateljski dvojici se nato pridruži Orestova sestra Ifigenija oziroma Stankova sestra Nataša.

Erinije so v Rebulovem pisanju močno prisotne in upodobljene kot maščevalke, oziroma preganjalke, ki popolnoma prevzamejo človekove misli in njegovo življenje. Po grški mitologiji so to pošastne boginje maščevanja, ki kaznujejo vsakršno kršitev javnega reda na zemlji tako, da človeka neprestano preganjajo. Tudi pisatelj sam je bil njihova žrtev, saj jih takole opisuje v svojem dnevniku:

Glej, sedanjost se razteče, praznina se nabije z grozo, vsenaokrog se nekaj prebuja, glava za glavo se dviga iz spanja, kačje lasišče za kačjim lasiščem: zbor Erinij, ki je osemnajst let spal. O kaj so počenjale, preden so zaspale! (Rebula 1989: 60)

Rebula je tako obseden z Erinijami, da jih v določenem trenutku vidi povsod, tudi v obliki stare murve, ki »v črni razpuščenosti svojega golega šibja, daje misliti na rastlinsko Erinijo..." (Rebula 1990: 27). Po Ajshilovi trilogiji se Orest, obseden od Erinij, zateče v Atene in se tam prepusti razsodbi Aeropaga, ki pa nima enotnega mnenja: polovica glasuje za Orestovo dokončno obsodbo in večno preganjanje Erinij, druga polovica pa se poteguje za njegovo pomilostitev. Dokončna odločitev pripada boginji modrosti in razumnosti, Ateni, ki glasuje v Orestovo korist. Demonske Erinije se takrat spremenijo v dobrohotne in blage Evmenide, s čimer zagotovijo Atenam večni mir in blaginjo. Tudi Stanko - Pilad tolaži svojega prijatelja s srečnim zaključkom: Amos - Orest bo morda nekega 
dne prav tako našel svoj večni mir, svoje blagoslovljene dni. Toda Amos v romanu ne najde zaželenega miru, saj se njegovo življenje tragično konča. Erinije ga namreč nenehno mučijo, tako da se jih ne more otresti, zato se odloči za ekstremno dejanje, s katerim se jih vendarle reši in končno zadiha večni mir.

Podoba Erinij pooseblja pri Rebuli ne le usodo posameznika, ampak slovenskega naroda nasploh, saj pisec pravi:

Zdi se, da se v zavesti Slovencev Evropa iz blage Evmenide, prinašalke mirne, srečne in bogate prihodnosti, spreminja v zloveščo Erinijo, prinašalko negotovosti in pogube. (Rebula 1998a: 6)

Orest, Erinije in Pilad pa niso edine figure iz grško-rimske mitologije, ki jih Rebula uporablja za svoje prispodobe. Med branjem je namreč mogoče zaslediti še celo vrsto znamenitih oseb, ki so postale monumentalni simboli najrazličnejših strasti, nagnjenj in človeških usod. Tako je npr. Mamea, Nemezianova mačeha v romanu $V$ Sibilinem vetru, prikazana kot strastna in ljubeča Medeja iz mita o Argonavtih, ovekovečena v svoji iracionalni ljubezni do Jazona.

Sredi mesnatih marmornatih odbleskov triklinija se mi je zazdela za hip kakor Medeja, gmota strasti $v$ rdečem žaru freske. (Rebula 1968: 311)

Ob njej pa se dviguje tudi podoba Apolona, boga luči, razuma in umetnosti. Čeprav se Rebula čuti zelo blizu bogu Dionizu, ki predstavlja sicer nasprotje Apolona, se preko svojih likov občasno vendarle proglasi tudi za Apolonovega učenca.

Rajši je ostal vernik boga luči, Apolona, kljub vsemu. Zapisan njegovemu solnemu lovišču intuicij in silogizmov. (Rebula 1980: 191)

Ob veličastnih mitoloških bitjih so pogosto izpostavljeni tudi zgodovinsko pomembni kraji. Tako nas npr. stavek »Velik korakje bil narejen. Rubikon je bil za mano ..." (Rebula 1998: 164) popelje pred odločilni dogodek, ko je Cezar v prvem stoletju pred Kristusom prekoračil s svojimi legijami Rubikon in prekršil zakon: vrnitve ni bilo več, dejanje je bilo storjeno!

Antika je večkrat omenjena tudi v Rebulovih ameriških dnevnikih, ko avtor primerja klasično kulturo z ameriško, ki sicer ima svoje korenine v evropski, in torej tudi v grški, pa se tega večkrat ne zaveda. Misel, da Amerika sploh ni dojela bistva grškega sporočila, izpostavlja tudi Alojz Rebula, ki je to celino obiskal trikrat in pravi, da

ni bila nikoli moja sanja, ameriški way of life - način življenja-se mi je zdel na antipodu mojega grškega koncepta življenja. (Rebula 1985: 8)

Pisec ugotavlja, da je skušal ameriški človek ohraniti evropsko tradicijo tudi na novih tleh in da se je v arhitekturi, literaturi in kulturi nasploh zgledoval po evropski antiki. Za nekatera svoja mesta je celo izbral imena iz grškega in rimskega sveta. Amerika nasploh teži k posnemanju evropske kulture in skuša doseči njeno raven, a dejansko ostaja le na ravni posnemanja in klasični kulturi ne daje novih, modernejših vsebin. Posnemanje je le zunanje, saj za globlje 
dojemanje grško-rimskega sveta Amerika ni dovzetna, tako da »zveni« njeno posnemanje zelo eksotično in na nepravem mestu (Rebula 1985: 183). Kljub vsemu pa Rebulo prevzame prijeten občutek, ko pomisli, da se novi svet skuša vsaj zgledovati po svojih prednikih.

Dejansko mi prija misel, da se je mlada Amerika v arhitekturi tako zazrla v Helado. In ali se oni periklejevski slog v gradnjah ne sklada s periklejevsko-krščansko vsebino Jeffersonovih proglasov? (Rebula 1985: 83)

V Rebulovem dnevniku Gorje zelenemu drevesu naletimo tudi na primerjavo med sodobnim intelektualnim svetom in aleksandrijsko dobo:

Ko smo Slovenci dobili poleg Slovenskega pravopisa še medicinski slovar, slovar pomorske slovenščine, splošni tehnični slovar, se zdaj Drago Druškovič v Naših razgledih ogreva tudi za politični slovar. Slovenci smo torej stopili v dobo slovarjev. Vse prav, dokler ne pozabimo, da imamo opravka z orodji. Sicer bo to doba našega aleksandrinizma. Zakaj samo duh je tisti, ki oživlja. (Rebula 1971: 27)

Aleksandrijska doba v Grčiji je čas, ko se je grški duh, ki se je razcvetel v Atenah v petem stoletju pred Kristusom, razširil po celem Sredozemlju. Njegovo središče je postala Aleksandrija, kulturo pa, ki je takrat kraljevala, bi lahko poimenovali za enciklopedično. Šlo je namreč za zbiranje in pisanje verzov in proze po zgledu grških piscev iz zlate dobe. Avtorji niso ustvarili nič novega, nič pristnega in izvirnega, kot so to storili pisci iz zlate dobe. V tej metafori Rebula poudarja, da postaja naša kultura le stvar oblike, ne pa vsebine, saj, podobno kot $\mathrm{v}$ aleksandrijski dobi, ne nastajajo dela $\mathrm{z}$ duhom, temveč samo dela, ki ciljajo k oblikovni brezhibnosti.

Tudi ko se Rebula zagleda $\mathrm{v}$ pojave zunanjega sveta, jih večkrat primerja $\mathrm{z}$ antičnimi:

Ob oknu, kjer sedim, gledam onkraj šipe precejanje dežja skozi marelico. Pred dva tisoč petsto leti je Sapfo gledala takšno precejanje skozi jablano. Vlivalo jo je v pozabo: koma katarrei. (Rebula 1996a: 247)

Podobnih metafor je še veliko, saj je v njih zajeta celotna Rebulova koncepcija antične miselnosti, kakor se zrcali v sodobnem svetu; celo črke, ki jih uporablja danes večina kulturnih narodov, so grškega izvora, sodobna arhitektura se je prav tako rodila na grških tleh, vse naše misli in ideje imajo svoj izvor v Grčiji.

Telefonske žice brnijo v vetru po grško. Od latinskega MARE do slovenskega MORJA je le nekaj vokalov. Openski obelisk tam gori nad zalivom je grški. Delavci, ki tamle iztovarjajo pesek iz trebuha tovornjače, si izmenjujejo cigaretni ogorek v spremenjeni latinščini. Polstebri na pročelju bližnje palače so grški. Črke, vklesane tamle v kamen, so grafično povzete iz rimskih napisov. Naša življenjska tesnoba, naš nepomirljivi $\underline{Z}$ a k a j, je grški. In navsezadnje je bila ideja socializma prej Platonova kakor Marxova. (Rebula 1971: 158)

Celotno naše bivanje je, kot pravi Rebula, le metafora antičnega sveta. "Danes mu odgovarjam, da mi Evropa ni nič več kot metafora« (Rebula 2000a: 21). 
$\mathrm{Ob}$ metaforiziranju antičnega in sodobnega sveta najde Rebula tudi tisto interakcijo, ki je skupna obema zgodovinskima obdobjema.

\section{Antika kot interakcija}

Pri analizi interakcije se bom osredotočila na Rebulove zadnje metafore, ki nakazujejo globljo miselno dimenzijo piščevih del. Z mitom o Piladu in Orestu se je pisatelj zaustavil ob pomembnem človekovem čustvu - ob prijateljski ljubezni. To obliko ljubezni, ki jo poznajo vsa zgodovinska obdobja, so stari Grki ponazorili z metaforo omenjene mitične dvojice, v kateri Pilad vestno in vztrajno spremlja nesrečnega Oresta v njegovem boju proti Erinijam. V tem primeru je Pilad oziroma prijateljstvo edina uteha, ki Orestu lajša trpljenje. Metafora o prijateljstvu se $\mathrm{v}$ tem mitu povezuje še $\mathrm{z}$ drugimi človeškimi napakami in zablodami, kot so: ljubezensko varanje, umor partnerja in umor lastne matere. To so pojavi, s katerimi se vsak dan srečuje tudi sodobni človek. Podoba Erinij, ki neprestano mučijo morilca in ga vznemirjajo, je prispodoba za slabo vest, katere se Orest reši le s pomočjo Atenine modrosti.

Z metaforo oziroma zgodbo o Kleobisu in Bitonu pa je Rebula ponazoril svoje tragično doživljanje sveta. Že stari Grk je namreč dojel dramatičnost življenja in si večkrat zaželel smrti. Podobni občutki prevzemajo tudi sodobnega človeka, ki si zato skuša od bogov izprositi smrt.

Zelo pogosta in znamenita metafora je tudi zgodba o Ojdipu in njegovem potomstvu, ki bo večno prekleto zaradi očetomora. To prekletstvo nosi v sebi tudi sodobno človeštvo, ki se pobija in uničuje v največji meri z bratomornimi vojnami. Nedvomno predstavlja Rebuli najbližji primer tovrstne krutosti boj med partizani in domobranci, ki je ustvaril po njegovem mnenju v slovenski zavesti tako globoke rane, da so skelele še dolgo let po vojni in ostajajo še vedno, vsaj podzavestno, nezaceljene. Zato slovenski narod potrebuje Antigono, ki bi pokopala zapuščenega brata in ga s tem rešila prekletstva bratomorne vojne. Pisatelj sicer vidi njen prihod oziroma možnost rešitve in sprave že v osamosvojitvi Slovenije, ki je prinesla slovenskemu narodu demokracijo in ga približala zahodni civilizaciji ter njenim koreninam.

Pomemben trenutek v zgodovini zahodne civilizacije je nedvomno prehod iz poganskega verovanja v monoteistično krščansko vero. Srečanje med tema dvema nasprotujočima si pogledoma na versko doživljanje je povzročilo veliko sporov in nasilja, Rebula pa je v krščanstvu kljub temu prepoznal naravno nadaljevanje poganskega etičnega sveta in humanistične miselnosti. Zato predstavlja zanj interakcijo oziroma stično točko med antičnim in sodobnim evropskim svetom prav humanitas ali anthropeja. Ta pa izstopa v idealu »etičnega in kulturnega povzdiga« (Rebula 2000a: 21), ki ga je bil zmožen antični človek. 


\section{Zaključek}

Analiza metafor iz klasičnega grško-rimskega sveta je pokazala bistveno razliko med obema sklopoma, ki je v tem, da je v prvem, torej v tistem, kjer je antika glavni predmet, grško-rimski svet v ospredju, avtor ga primerja in osvetljuje z najrazličnejšimi elementi. V drugem primeru pa je postopek obraten: središčno vlogo ima sedanja doba, ki jo pisatelj primerja $\mathrm{z}$ antično. Tretja in najgloblja raven, interakcija, nam razkriva dimenzijo, v kateri imata oba svetova, sedanji in antični, svoje stične točke. Ta dimenzija je izredno subjektivne narave, saj gre za Rebulov osebni odnos do obeh svetov in predstavlja tiste vsesplošne človeške vrednote in silnice, ki so prisotne tako v antičnem kot v sodobnem svetu.

\section{LITERATURA}

ARISTOTEL, 1982: Poetika. Prev. Katejatan Gantar. Ljubljana: Cankarjeva založba. Max BLACK, 1998: Metafora. Kaj je metafora? Ur. Božidar Kante. Ljubljana: Krt. 91-138.

Jadranka CERGOL; 2006: Percepcija klasičnih grško-rimskih filozofskih kategorij v delih slovenskega pisatelja Alojza Rebule. Jezik in slovstvo, 51/6, 67-79.

- -, 2011: Antika in krščanstvo: miselna paradigma Alojza Rebule. Annales, Series Historia et Sociologia, 2, 379-388.

Jožica ČEH STEGER, 2005: Pogledi na metaforo. Jezik in slovstvo, 3-4, 75-86.

Kajetan GANTAR, 2005: Rebula in antika. Rebulov zbornik: ob pisateljevi osemdesetletnici. Ur. Lojzka Bratuž. Trst, Gorica, Videm: Mladika, Goriška Mohorjeva družba, Slavistično društvo. 35-45.

Gerhard KURZ, 1986: Metapher, Allegorie, Symbol. Gottingen: Vandenhoeck \& Ruprecht.

Vanesa MATAJC, 1996: Metafora in simbol (diplomsko delo). Ljubljana: Filozofska fakulteta.

Alojz REBULA, 1968: V Sibilinem vetru. Ljubljana: Slovenska matica.

- -, 1971: Gorje zelenemu drevesu. Maribor: Obzorja.

--, 1981: Zeleno izgnanstvo. Ljubljana: Slovenska matica.

--, 1985: Oblaki Michigana. Celovec: Mohorjeva založba.

- -, 1986: Vrt bogov. Ljubljana: Slovenska matica.

- -, 1986a: Dnevnik 1969. Celovški zvon, 4/12, 63-66.

- -, 1989: Dnevnik 1969. Celovški zvon, 7/22, 58-61.

- -, 1990: Dnevnik 1969. Celovški zvon, 7/26, 14-17.

- -, 1991: Na slovenskem poldnevniku. Maribor: Obzorja. 
--, 1993: Dnevnik 1970. Celovški zvon, 11/41, 28-33.

- -, 1994: Kačja roža. Ljubljana: Mihelač.

- -, 1994a: Dnevnik 1971. Celovški zvon, 12/45, 29-32.

- -, 1995: Dnevnik 1971. Celovški zvon, 13/47, 32-36.

- -, 1996: Maranathà ali leto 999. Celovec: Mohorjeva založba.

- -, 1996a: Previsna leta. Trst: Mladika.

- -, 1998: Cesta s cipreso in zvezdo. Trst: Mladika.

- -, 1998a: Credo. Družina, 47/22, 6.

- -, 2000: Ko proti jutru gre. Celovec: Mohorjeva založba.

- -, 2000a: Dnevnik 1986. Zvon, 3/1, 10-14.

--, 2001: Dnevnik 1986. Zvon, 4/4, 19-23.

- -, 2011: Moj odnos do antike. Keria: studia Latina et Graeca, 13/1, 91-94.

Armstrong I. RICHARDS, 1998: Metafora. Kaj je metafora? Ur. Božidar Kante. Ljubljana: Krt. 43-72.

\section{METAPHORS FROM THE GRAECO-ROMAN WORLD IN THE WORKS OF THE SLOVENE WRITER ALOJZ REBULA}

The author of this paper presents an analysis of those metaphors in Rebula's opus that comprehend Graeco-Roman subject matter. Based on the interaction theory of metaphor the examples can be divided into two categories: metaphors with classical antiquity as the primary subject and metaphors with classical antiquity as the secondary subject. In the last part of the paper the author presents her findings about the types of interaction that combine both kinds of metaphor. The analysis of metaphors from the classical Graeco-Roman world shows that in the first case, which sees classical antiquity as the primary subject, the writer put the Graeco-Roman world in the forefront, comparing and explaining it through various elements. The roles are reversed in the second case, where present day situations are highlighted and compared with the classical period. The third and the deepest level of the metaphor, the interaction, unveils a new dimension, in which the two worlds, the present day and the classical period, meet. This dimension is of a remarkably subjective nature as it represents Rebula's personal relation to both worlds as well as those general human values and motives that are common to both the classical and the modern era. 